\title{
Climate change and the new normal for cardiorespiratory disease
}

\author{
Tim K Takaro MD MPH MS ${ }^{1}$, Sarah B Henderson PhD²,3
}

TK Takaro, SB Henderson. Climate change and the new normal for cardiorespiratory disease. Can Respir J 2015;22(1):52-54.

Climate change is already affecting the cardiorespiratory health of populations around the world, and these impacts are expected to increase. The present overview serves as a primer for respirologists who are concerned about how these profound environmental changes may affect their patients. The authors consider recent peer-reviewed literature with a focus on climate interactions with air pollution. They do not discuss in detail cardiorespiratory health effects for which the potential link to climate change is poorly understood. For example, pneumonia and influenza, which affect $>500$ million people per year, are not addressed, although clear seasonal variation suggests climate-related effects. Additionally, large global health impacts in low-resource countries, including migration precipitated by environmental change, are omitted. The major cardiorespiratory health impacts addressed are due to heat, air pollution and wildfires, shifts in allergens and infectious diseases along with respiratory impacts from flooding. Personal and societal choices about carbon use and fossil energy infrastructure should be informed by their impacts on health, and respirologists can play an important role in this discussion.

Key Words: Air pollution; Cardiorespiratory disease; Climate change; Floods; Forest fires; Heat effects

$\mathrm{T}$ he global environment is undergoing profound change due to increases in temperatures and changes in the hydrological cycle (1). Climate change is a serious public health threat, both globally and nationally. In a recent update, the WHO estimated that 250,000 additional deaths per year will be caused by climate change between 2030 and 2050 (2). In addition to increased mortality, millions of disability-affected life-years will be lost annually due to climate change impacts over the previous three decades (3). Although the burden of these effects is disproportionately distributed to low-income countries, the health of the Canadian population is also affected. Although more exhaustive reviews have summarized and described the observed and potential impacts (4), our objective is to provide a brief overview from a Canadian perspective.

A growing body of epidemiological literature specifically associates climate change with changing distributions of cardiorespiratory disease and mortality $(1,4-8)$, which includes both direct and indirect effects. The indirect effects include shifts in allergen load, changes in the distribution of vector-borne illnesses, and societal disruptions that can change risk factors for populations affected by extreme events, sea level rise and forced migration (9-11). The more direct effects include heat-related exacerbations of conditions such as asthma, chronic obstructive pulmonary disease (COPD) and cardiovascular disease (CVD), increases in hazardous air pollution days from ozone and particulate matter, and mortality and morbidity from extreme weather events and their aftermaths $(9,10,12)$. We highlight some specific examples of impacts that should be considered by Canadian respirologists.

\section{AIR POLLUTION (ASTHMA AND COPD)}

Increasing atmospheric temperatures and related meteorological effects can worsen ground-level pollution, most notably ozone (12-14), leading to diminished lung function, increased health care utilization and

\section{Les changements climatiques et la nouvelle réalité des maladies cardiorespiratoires}

Les changements climatiques ont déjà des conséquences sur la santé cardiorespiratoire des populations du monde, et ces conséquences sont appelées à augmenter. Le présent aperçu fournit des notions élémentaires aux pneumologues qui s'inquiètent de l'effet de ces profonds changements environnementaux sur leurs patients. Les auteurs examinent les publications récentes qui ont été révisées par des pairs et qui traitent des interactions du climat avec la pollution de l'air. Ils ne détaillent pas les effets des changements climatiques potentiels, mais mal compris, sur la santé respiratoire. Par exemple, ils n'abordent pas la pneumonie et la grippe, qui touchent plus de 500 millions de personnes par année, même si les évidentes variations saisonnières laissent entrevoir des effets liés au climat. De plus, ils passent sous silence l'incidence considérable du climat sur la santé dans les pays pauvres en ressources, y compris la migration provoquée par les changements environnementaux. Les principaux effets sur la santé cardiorespiratoire sont attribuables à la chaleur, à la pollution de l'air et aux incendies de forêt, aux modifications des allergènes et des maladies infectieuses ainsi qu'aux inondations. Les répercussions du carbone et de l'infrastructure des énergies fossiles sur la santé devraient influer sur les choix personnels et sociétaux à l'égard de leur utilisation. Les pneumologues peuvent jouer un rôle important dans ces discussions.

premature death. Individuals with COPD, CVD, diabetes and chronic ozone exposures are at particular risk (15). The highest burden of these conditions falls disproportionately on lower-income members of society, who frequently reside in more polluted areas (16). Climate change can also lead to higher atmospheric concentrations of fine particulates $\left(\mathrm{PM}_{2.5}\right)(17,18)$. The predicted increase in temperatures threatens our ability to meet health-based air quality standards in the future.

\section{WILDFIRES (ALL RESPIRATORY AND CVD)}

Wildfires cause episodes of the worst air pollution that most Canadians will ever experience. Higher temperatures and increasing drought contribute to greater wildfire risk, and recent analyses by the Canadian Forest Service suggest that annual average fire activity could double by the end of the century due to climatic changes (19). This increase in fire risk is driven by warmer spring and summer temperatures, reduced precipitation and snowpack, earlier snowmelt and prolonged summer fire seasons at higher elevations (20). Warmer temperatures also put forests at risk for new and more widespread threats that further increase fire risk. For example, the mountain pine beetle has devastated lodgepole pine in British Columbia (BC) and may threaten other areas of the country (21). In fact, the annual average area burned in $\mathrm{BC}$ has increased drastically since the beginning of the infestation. The 2014 fire season was extreme throughout Western Canada, with $>4.2$ million hectares burned in $>3500$ fires west of Manitoba. While $40 \%$ of these fires were in BC, $80 \%$ of the burned area was in the Northwest Territories, where much of the population was exposed to dense smoke for extended periods of time.

Wildfire smoke is a complex mixture of particulates and gases that are known to have acute and chronic health effects $(22,23)$. Most of the epidemiological research focuses on increased $\mathrm{PM}_{2.5}$ during smoke episodes, which has been associated with a spectrum of acute respiratory impacts $(24,25)$ including symptoms of pain, irritation, cough and

${ }^{1}$ Faculty of Health Sciences, Simon Fraser University, Burnaby; ${ }^{2}$ Environmental Health Services, British Columbia Centre for Disease Control;

${ }^{3}$ School of Population and Public Health, University of British Columbia, Vancouver, British Columbia

Correspondence: Dr Tim K Takaro, Faculty of Health Sciences, Simon Fraser University, 8888 University Drive, Burnaby,

British Columbia V5A 1S6. Telephone 778-782-7196, e-mail ttakaro@sfu.ca 
phlegm (26), increases in medications dispensed (27), outpatient physician visits (28), emergency room visits (29), hospital admissions (30) and mortality (31). Further evidence suggests that babies in the womb during smoke events are at higher risk for low birth weight (32), with lifelong health implications. There have not been any studies investigating the long-term impacts of wildfire smoke exposure on children and adults. However, we know from the literature on urban air pollution that increased annual average $\mathrm{PM}_{2.5}$ concentrations are associated with increased rates of chronic respiratory and CVDs in the population (33). As emissions from transportation and industrial sources come under better control, we expect that wildfire smoke will play an increasingly important role in lifetime exposure to $\mathrm{PM}_{2.5}$ and, therefore, in the development of chronic diseases (34). One recent worldwide study estimated that an average of 339,000 deaths could be attributed to the acute and chronic impacts of wildfire smoke each year (35). These health threats could increase in the future as climate change exacerbates wildfire risks in Canada and around the world (36).

\section{CHANGES IN POLLEN RELEASES (ASTHMA AND ALLERGIC RHINITIS)}

Aero-allergenic plant pollen production and distribution is impacted by climate change, with several-fold increases in tree, grass and weed pollen demonstrated under higher carbon dioxide concentrations $(37,38)$ and with extended growing seasons. In midwestern North America between 1995 and 2009, ragweed production increased up to 27 pollination days over the year (39). Increases in ambient pollen concentrations are associated with higher rates of allergic sensitization, higher health care utilization and large increases in over-thecounter allergy medication sales $(4,12,40-45)$. Drought conditions are also predicted to increase, and can worsen these impacts as more pollen, dust and particulates become airborne in dry conditions.

\section{HEATWAVES (COPD, CVD)}

Over the past 60 years, average annual temperatures in Canada have increased by $>1.5^{\circ} \mathrm{C}(6)$. During multiday heatwave periods, additional deaths can range into the tens of thousands, as in the 2003 European and 2010 Russian heatwaves, among other notable events. Extreme heat increases short-term premature mortality and morbidity from a variety of causes, including those directly heat-related (heat stroke, heat syncope, heat edema, etc) and a range of cardiovascular, respiratory, kidney and other illnesses $(7,46,47)$. Increased temperature variability can also increase mortality among elderly patients (48), even in typically moderate climates such as Vancouver, BC (49).

\section{STORMS, FLOODING AND MOULD EXPOSURE}

Climate change is predicted to increase the intensity of storm events. Thunderstorm activity has been associated with asthma exacerbations in North America, Europe and Australia $(50,51)$ due to the breakage and wide dispersion of pollens by the turbulent atmosphere. More intense storms also lead to increased precipitation, which has been observed across most parts of Canada over the past 60 years (6). More precipitation will also lead to more flooding (52), which threatens health infrastructure, even in wealthy countries. Patients requiring mechanical ventilation and intensive care are particularly vulnerable due to the challenges posed by evacuation and power outages (53). Multiple health care facilities were evacuated during the unprecedented 2013 floods in Alberta (www.drieottawa.org/presentations/20141017/20141017_tom_watts.pdf), although specific impacts of the floods have not been published to date. Resource-poor facilities are likely to be even more vulnerable to extreme weather threats.

Floods and persistent dampness in homes can promote microbial growth, particularly moulds. High indoor/outdoor mould ratios were observed in the months following Hurricanes Rita and Katrina, indicating the potential for high indoor exposures (54). Mould levels may increase under climate change due to increased moisture in building materials and indoor dampness, increased temperatures and elevated carbon dioxide concentrations that encourage growth (54,55-57). In immune-competent individuals, respiratory illness associated with mould exposure is due to fungal elements that may be allergens or respiratory irritants, leading to exacerbations of allergic rhinitis and asthma (58). In immune-compromised individuals or those with concomitant pulmonary disease, fulminant fungal infections, such as aspirgillosis, may ensue (59).

\section{MITIGATION AND CARDIORESPIRATORY HEALTH}

Mitigation of greenhouse gas (GHG) emissions to reduce future impacts is a critical challenge for society; however, adaptation to the inevitable increases in temperature will also be required. There is significant uncertainty about the range of projected average surface temperatures in the future; this uncertainty increases with efforts to predict more local changes (1). There is even greater uncertainty in predicting precipitation (1). Some of this is due to the fact that we cannot accurately project future human behaviour that drives GHG emissions. Although societal efforts to achieve meaningful GHG reductions targets will be challenging, the benefits to cardiorespiratory health are significant and can be more immediate and tangible than reductions in GHGs (60). These include reduction in health-harming copollutants emitted with GHGs, and reduction in natural hazards such as wildfires and floods. The improvements in health have already been observed in indoor dampness and in conditions where emissions are being reduced in Europe, including in electricity generation and household energy use, transportation, food production and agriculture (60). Cobenefits include increased physical activity, reduced air pollution, more efficient and available food production, reforestation and improved overall quality of urban living (61). As noted in a special issue of The Lancet, "The news is not all bad" (62).

\section{CONCLUSIONS}

It is difficult for individuals to feel empowered in the face of something as vast and daunting as climate change. We can make personal choices and contribute to community efforts, but the challenge will continue to involve large energy infrastructure and be global in scope (63). Nevertheless, respirologists can play an important role because climate change will significantly affect cardiorespiratory health and is, therefore, an issue of considerable importance to individuals and governments. To date, human health, particularly cardiorespiratory health, has not been central to the climate change and energy dialogue in Canada. Many Canadians may not be well informed about direct threats to their cardiorespiratory health from the increased wildfires, hot weather events, air pollution, flooding, mould and longer pollen seasons that are predicted over the coming decades. Respirologists have a unique opportunity to build public interest in this issue by making it relevant to something in which most individuals have profound interest: protecting the health of their families now and for future generations.

ACKNOWLEDGEMENTS: The authors thank Kim Knowlton and John $\mathrm{R}$ Balmes for their bibliographies, and Agnes T Black for editing assistance.

DISCLOSURES: The authors have no conflicts of interest to declare.

\section{REFERENCES}

1. Allan RP, Soden BJ. Atmospheric warming and the amplification of precipitation extremes. Science 2008;321:1481-4.

2. WHO. Quantitative risk assessment of the effects of climate change on selected causes of death, 2030s and 2050s. Geneva: WHO, 2014.

3. Patz JA, Campbell-Lendrum D, Holloway T, Foley JA. Impact of regional climate change on human health. Nature 2005;438:310-7.

4. Pinkerton KE, Rom WN, Akpinar-Elci M, et al. An official American Thoracic Society workshop report: Climate change and human health. Proc Am Thorac Soc 2012;9:3-8.

5. Field CB, Barros V, Stocker TF, et al; IPCC, eds. Managing the Risks of Extreme Events and Disasters to Advance Climate Change Adaptation. A Special Report of Working Groups I and II of the Intergovernmental Panel on Climate Change. IPCC 2012:1-582.

6. Warren FJ, Lemmen DS, eds. Canada in a Changing Climate: Sector Perspectives on Impacts and Adaptation. Ottawa: Government of Canada, 2014:286.

7 Ye X, Wolff R, Yu W, Vaneckova P, Pan X, Tong S. Ambient temperature and morbidity: A review of epidemiological evidence. Environ Health Perspect 2012;120:19-28. 
8. Centers for Disease Control and Prevention, U.S. Environmental Protection Agency, National Oceanic and Atmospheric Agency, American Water Works Association. When every drop counts: Protecting public health during drought conditions - a guide for public health professionals, 2010. <www.cdc.gov/nceh/ehs/publications/ drought.htm> (Accessed December 6, 2014).

9. McMichael AJ, Woodruff RE, Hales S. Climate change and human health: Present and future risks. Lancet 2006;367:859-69.

10. McMichael C, Barnett J, McMichael AJ. An ill wind? Climate change, migration, and health. Environ Health Perspect 2012;120:646-54.

11. Solomon S, Qin D, Manning M, et al, eds; IPCC. Climate Change 2007: The Physical Science Basis. Contribution of Working Group I to the Fourth Assessment Report of the Intergovernmental Panel on Climate Change. IPCC 2007:1-996.

12. Kinney PL. Climate change, air quality, and human health. Am J Prev Med 2008;35:459-67.

13. Jacob DJ, Winner DA. Effect of climate change on air quality. Atmos Environ 2009;43:51-63.

14. Isaksen IS, Granier C, Myhre G, et al. Atmospheric composition change: Climate-chemistry interactions. Atmos Environ 2009;43:5138-92.

15. Zanobetti A, Schwartz J. Ozone and survival in four cohorts with potentially predisposing diseases. Am J Respir Crit Care Med 2011;184:836-41.

16. Clark LP, Millet DB, Marshall JD. National patterns in environmental injustice and inequality: Outdoor $\mathrm{NO}_{2}$ air pollution in the U.S. PLoS One 2014;9:e94431.

17. Avise J, Chen J, Lamb B, et al. Attribution of projected changes in summertime US ozone and PM2.5 concentrations to global changes. Atmos Chem Physics 2009;9:1111-24.

18. Tai AP, Mickley LJ, Jacob DJ. Correlations between fine particulate matter $\left(\mathrm{PM}_{2.5}\right)$ and meteorological variables in the United States: Implications for the sensitivity of PM2.5 to climate change. Atmos Environ 2010;44:3976-84.

19. Dennekamp M, Abramson MJ. The effects of bushfire smoke on respiratory health. Respirology 2011;16:198-209.

20. Westerling A, Bryant B. Climate change and wildfire in California. Clim Change 2008;87:231-49.

21. Elliott CT, Henderson SB. Time series analysis of fine particulate matter and asthma reliever dispensations in populations affected by forest fires. Environ Health 2013;12:1-9.

22. Henderson SB, Brauer M, MacNab YC, et al. Three measures of forest fire smoke exposure and their associations with respiratory and cardiovascular health outcomes in a population-based cohort. Environ Health Perspect 2011;119:1266.

23. Delfino RJ, Brummel S, Wu J, et al. The relationship of respiratory and cardiovascular hospital admissions to the southern California wildfires of 2003. Occup Environ Med 2009;66:189-97.

24. Henderson SB, Johnston FH. Measures of forest fire smoke exposure and their associations with respiratory health outcomes. Curr Opin Allerg Clin Immunol 2012;12:221-7.

25. Holstius DM, Reid CE, Jesdale BM, et al. Birth weight following pregnancy during the 2003 Southern California wildfires. Environ Health Perspect 2012;120:1340-5.

26. Kolbe A, Gilchrist KL. An extreme bushfire smoke pollution event: Health impacts and public health challenges. N S W Public Health Bull 2009;20:19-23.

27. Morgan G, Sheppeard V, Khalaj B, et al. Effects of bushfire smoke on daily mortality and hospital admissions in Sydney, Australia. Epidemiology 2010;21:47-55.

28. Naeher LP, Brauer M, Lipsett M, et al. Woodsmoke health effects: A review. Inhal Toxicol 2007;19:67-106.

29. Pope III C, Burnett RT, Thun MJ, et al. Lung cancer, cardiopulmonary mortality, and long-term exposure to fine particulate air pollution. JAMA 2002;287:1132-41

30. Rappold AG, Stone SL, Cascio WE, et al. Peat bog wildfire smoke exposure in rural North Carolina is associated with cardiopulmonary emergency department visits assessed through syndromic surveillance. Environ Health Perspect 2011;119:1415.

31. Safranyik L, Carroll AL, Régnière J, et al. Potential for range expansion of mountain pine beetle into the boreal forest of North America. Can Entomol 2010;142:415-42.

32. Sahani M, Zainon NA, Wan Mahiyuddin WR, et al. A case-crossover analysis of forest fire haze events and mortality in Malaysia. Atmos Environ 2014;96:257-65.

33. Wotton BM, Nock CA, Flannigan MD. Forest fire occurrence and climate change in Canada. Int J Wildland Fire 2010;19:253-71.

34. Yue X, Mickley LJ, Logan JA, et al. Ensemble projections of wildfire activity and carbonaceous aerosol concentrations over the western United States in the mid-21st century. Atmos Environ 2013;77:767-80.
35. Johnston FH, Henderson SB, Chen Y, et al. Estimated global mortality attributable to smoke from landscape fires. Environ Health Perspect 2012;120:695-701.

36. Spracklen DV, Mickley LJ, Logan JA, et al. Impacts of climate change from 2000 to 2050 on wildfire activity and carbonaceous aerosol concentrations in the western United States. J Geophys Res 2009;114:D20301.

37. Ziska LH, Beggs PJ. Anthropogenic climate change and allergen exposure: The role of plant biology. J Allergy Clin Immunol 2012;129:27-32.

38. Ziska LH, Epstein PR, Rogers CA. Climate change, aerobiology, and public health in the Northeast United States. Mitigation Adapt Strat Global Change 2008;13:607-13.

39. Ziska L, Knowlton K, Rogers C, et al. Recent warming by latitude associated with increased length of ragweed pollen season in central North America. Proc Natl Acad Sci U S A 2011;108:4248-51.

40. D'Amato G. Effects of climatic changes and urban air pollution on the rising trends of respiratory allergy and asthma. Multidiscip Respir Med 2011;6:28-37.

41. Darrow LA, Hess J, Rogers CA, Tolbert PE, Klein M, Sarnat SE. Ambient pollen concentrations and emergency department visits for asthma and wheeze. J Allergy Clin Immunol 2012;130:630-8,e4.

42. Forsberg B, Braback L, Keune H, et al. An expert assessment on climate change and health - with a European focus on lungs and allergies. Environ Health 2012;11(Suppl 1):S4

43. Reid CE, Gamble JL. Aeroallergens, allergic disease, and climate change: Impacts and adaptation. Ecohealth 2009;6:458-70.

44. Shea KM, Truckner RT, Weber RW, Peden DB. Climate change and allergic disease. J Allergy Clin Immunol 2008;122:443-53.

45. Sheffield PE, Weinberger KR, Kinney PL. Climate change, aeroallergens, and pediatric allergic disease. Mt Sinai J Med 2011;78:78-84.

46. Knowlton K, Rosenthal JE, Hogrefe C, et al. Assessing ozone-related health impacts under a changing climate. Environ Health Perspect 2004;112:1557-63.

47. Gamble JL, Hurley BJ, Schultz PA, Jaglom WS, Krishnan N, Harris M. Climate change and older Americans: State of the science. Environ Health Perspect 2012;121:15-22.

48. Zanobetti A, O’Neill MS, Gronlund CJ, Schwartz JD. Summer temperature variability and long-term survival among elderly people with chronic disease. Proc Natl Acad Sci U S A 2012;109:6608-13.

49. Kosatsky T, Pollock SL, Henderson SB. Shifts in mortality during a hot weather event in Vancouver, Canada: Rapid assessment with case-only analysis. Am J Public Health 2012;102:2367-71.

50. Villeneuve PJ, Leech J, Bourque D. Frequency of emergency room visits for childhood asthma in Ottawa, Canada: The role of weather. Int J Biometeorol 2005;50:48-56.

51. D'Amato G, Liccardi G, Frenguelli G. Thunderstorm-asthma and pollen allergy. Allergy 2007;62:11-16.

52. Webster PJ, Holland GJ, Curry JA, Chang HR. Changes in tropical cyclone number, duration, and intensity in a warming environment. Science 2005;309:1844-6.

53. Brevard SB, Weintraub SL, Aiken JB, et al. Analysis of disaster response plans and the aftermath of hurricane Katrina: Lessons learned from a level I trauma center. J Trauma 2008;65:1126-32.

54. Barbeau DN, Grimsley LF, White LE, El-Dahr JM, Lichtveld M. Mold exposure and health effects following hurricanes Katrina and Rita. Annu Rev Public Health 2010;31:165-78.

55. Institute of Medicine. Climate Change, the Indoor Environment, and Health. Washington, DC: The National Academies Press, 2011.

56. Rabito FA, Perry S, Davis WE, Yau CL, Levetin E. The relationship between mold exposure and allergic response in post-Katrina New Orleans. J Allergy (Cairo) 2010;510380 (Epub June 16, 2010).

57. Wolf J, O’Neill NR, Rogers CA, Muilenberg ML, Ziska LH. Elevated atmospheric carbon dioxide concentrations amplify Alternaria alternata sporulation and total antigen production. Environ. Health Perspect 2010;118:1223-8.

58. Institute of Medicine. Damp Indoor Spaces and Health. Washington, DC: The National Academies Press, 2004.

59. Kosmidis C, Denning DW. The clinical spectrum of pulmonary aspergillosis. Thorax October 29, 2014 (Epub ahead of print).

60. Ganten D, Haines A, Souhami R. Health co-benefits of policies to tackle climate change. Lancet 2010;376:1802-4.

61. Cheng JJ, Berry P. Health co-benefits and risks of public health adaptation strategies to climate change: A review of current literature. Int J Public Health 2013;58:305-11.

62. The Lancet Series. The health benefits of tackling climate change: An executive summary for The Lancet Series, 2012 (10/30) (2009)

63. IPCC 5th Assessment Synthesis Report: Approved summary for policy makers. November 1, 2014. <www.ipcc.ch/report/ar5/syr/> (Accessed December 29, 2014). 


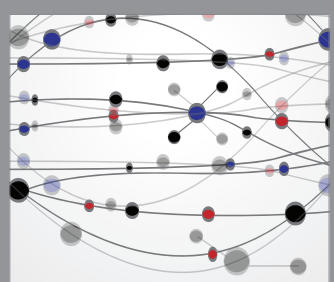

The Scientific World Journal
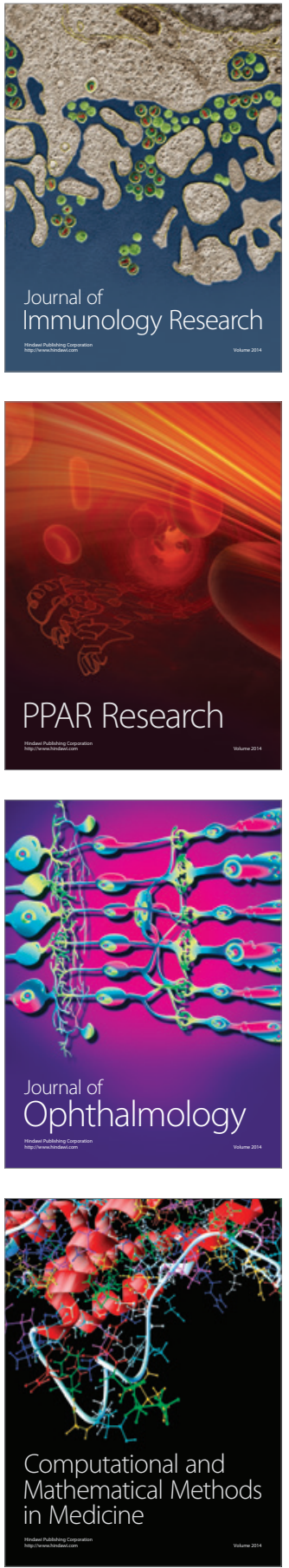

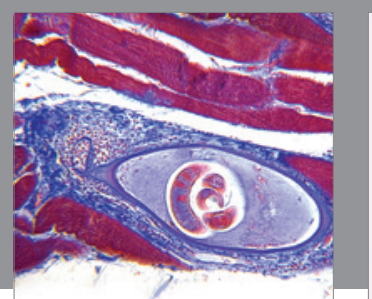

Gastroenterology Research and Practice

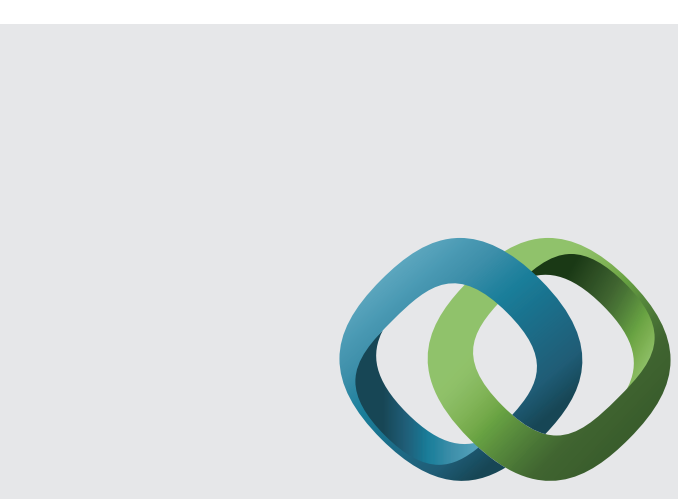

\section{Hindawi}

Submit your manuscripts at

http://www.hindawi.com
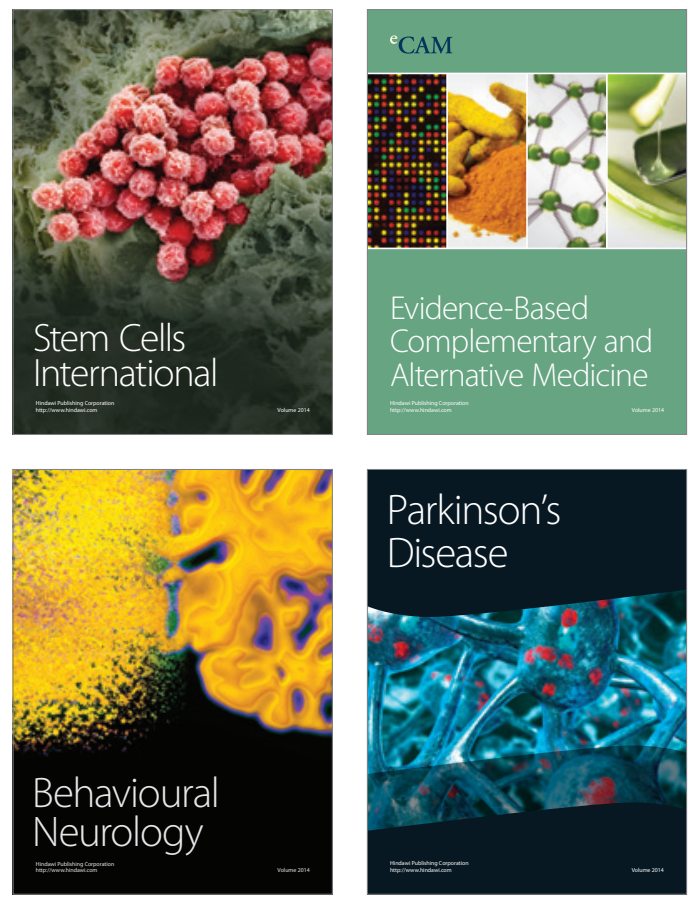
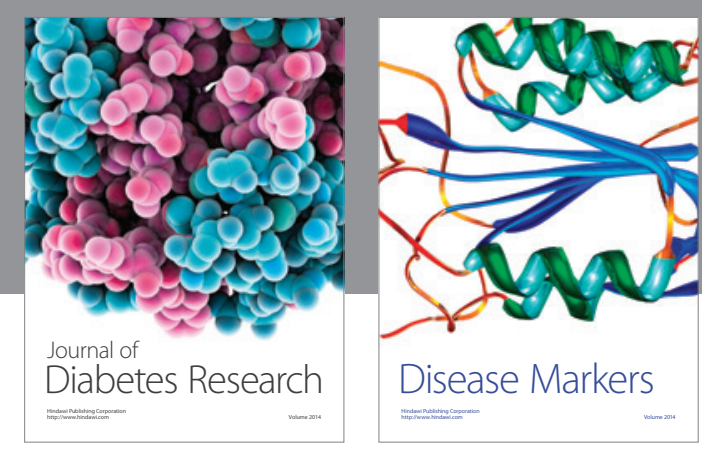

Disease Markers
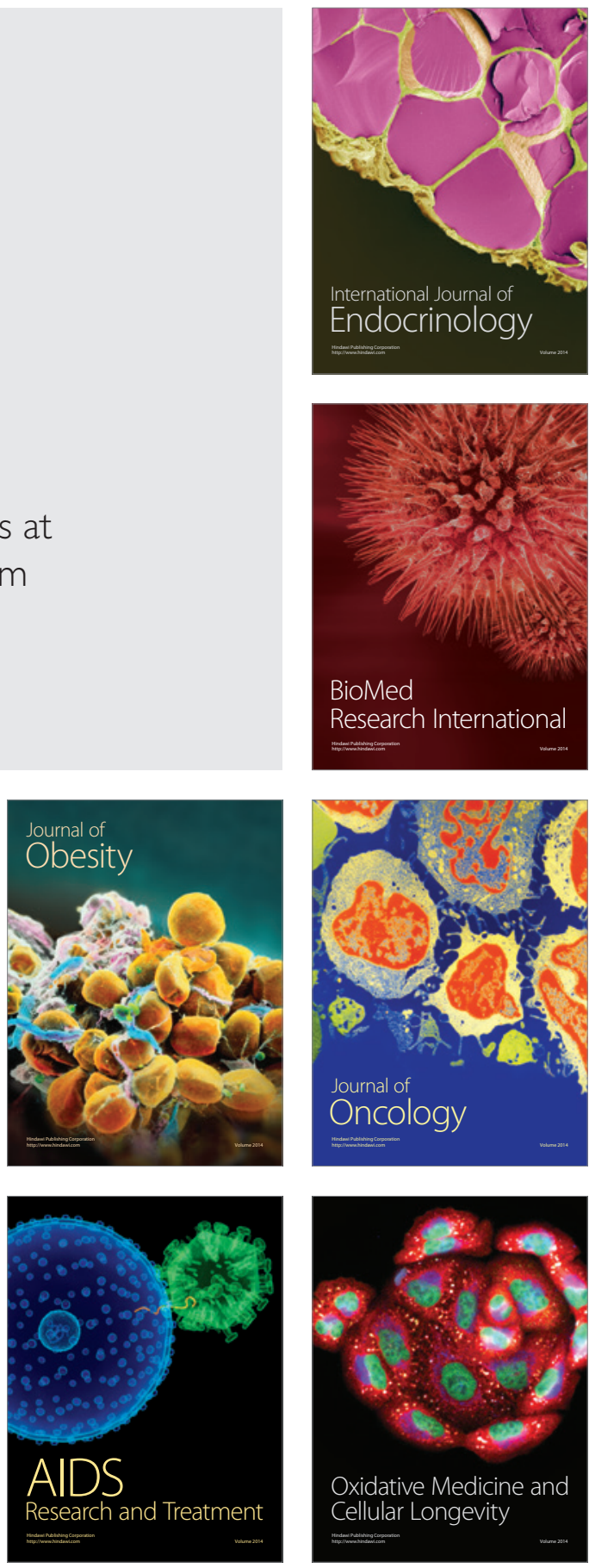